\title{
KOMUNITAS BACA DALAM MENYEBAR VIRUS LITERASI \\ "PERPUSTAKAAN JALANAN DIY"
}

\author{
Aras Satria Agusta \\ Mahasiswa UIN Sunan Kalijaga Yogyakarta \\ Email: arassatria.agusta@gmail.com
}

\begin{abstract}
Abstrak
Kegiatan membaca merupakan suatu tradisi dan aktivitas bagi orang yang menginginkan pengetahuan yang lebih mendalam, memiliki rasa optimis untuk suatu kesuksesan baik dalam pendidikan, bisnis, pemerintahan dan aktivitas sosial kemasyarakatan. Berbagai komunitas literasi memiliki keunikan sendiri dalam menyebarkan semangat literasi seperti mengadakan lapak atau lesehan bacaan berupa buku, majalah, artikel-artikel, dan beberapa koleksi novel dan komik untuk anak-anak, remaja maupun dewasa. Dalam tulisan ini lebih memfokuskan bagaimana aktivitas dari komunitas tersebut berjalan dan mempengaruhi masyarakat dalam peningkatan literasi. Kajian dilakukan pada komunitas literasi Perpustakaan Jalanan DIY dimana komunitas ini merupakan suatu kesatuan antara anggotanya yang memiliki semangat untuk menyebar literasi, dengan identitas terhadap penyatuan visi yang sama.
\end{abstract}

Kata kunci: Komunitas, Literasi

\begin{abstract}
Reading activities are a tradition and activities for people who want deeper knowledge, have a sense of optimism for a success both in education, business, government and social activities. Various literacy communities have their own uniqueness in spreading the spirit of literacy such as holding shades or reading books in the form of books, magazines, articles, and several collections of novels and comics for children, adolescents and adults. In this paper the focus is more on how the activities of the community work and influence the community in increasing literacy. The study was conducted on the DIY Street Library literacy community where this community is a unity between its members who have the passion to spread literacy, with an identity towards the unity of the same vision.
\end{abstract}

Keywords: Community, Literacy 


\section{PENDAHULUAN}

Perkembangan ilmu pengetahuan dan teknologi yang terjadi pada abad ke-21 saat ini, seakan mengantarkan kita pada beberapa fenomena, katakanlah itu dalam perubahan perilaku masyarakat, budaya, dan perubahan terhadap media komunikasi. Pada masa revolusi industri 4.0 maka bersamaan itu perubahan karakter dan perilaku masyarakatpun berevolusi. Berbagai pendidikan dan pembelajaran diberikan oleh lembaga pendidikan seperti sekolah, perpustakaan, lembaga kursus, dan beberapa gerakan komunitas baca, mereka telah melakukan semaksimal mungkin terhadap gerakan literasi. Tetapi untuk hasil belumlah maksimal, masih banayak PR atau beberapa problem yang harus dipecahkan bersama.

Pada aspek pendidikan tentunya tidak bisa dilepaskan dari konteks membaca, membaca dalam artian baik dengan menggunakan media cetak seperti buku atau media elektronik seperti komputer, laptop dan android, hal ini tidak bisa terlepas dari konteks perubahan masyarakat industri. Membaca memiliki makna sebagai penentu suatu kesuksesan, banyak orang-orang sukses bahkan menjadi seorang tokoh dengan membaca dan dapat menganalisis bacaanya dalam kehidupan bermasyarakat. Hartono mengatakan, membaca bukan merupakan suatu pewarisan sifat yang secara turun-temurun atau suatu yang diwarisi, tetapi membaca ialah kegiatan dapat berkembang melalui pembinaan $^{7}$ dan pendampingan, serta dukungan sosial masyarakat.

Untuk melihat kemajuan suatu peradaban dalam kebangsaan maka sudah pasti didukung oleh semangat dalam membangun nalar ideologis terhadap sumber daya manusianya.

${ }^{7}$ Hartono, dasar-dasar Manajemen Perpustakaan dari Masa ke Masa (Malang: UIN Maliki Press, 2015), 265. 
Penguasaan terhadap berbagai ilmu pengetahuan akan didapatkan melalui berbagai gate baik itu perpustakaan, internet, taman bacaan masyarakat dan berbagai komunitas literasi. Di Indonesia oleh kementerian pendidikan dan kebudayaan mengatakan, untuk sumber daya pelaku dan pegiat literasi harus ditingkatkan pertahapan dirancang agar berjalan berkesinambungan tanpa jeda. ${ }^{8} \mathrm{Hal}$ ini menunjukkn adanya semangat masyarakat Indonesia untuk menyebarkan virus literasi. Literasi dapat dilakukan oleh siapa saja tidak memandang latar belakang dari pegiatnya, literasi juga merupakan suatu program yang durasinya jangka panjang dan berkesinambungan, berbagai komunitas literasi memiliki keunikan sendiri dalam menyebarkan semangat literasi seperti mengadakan lapak atau lesehan bacaan berupa buku, majalah, artikel-artikel, dan beberapa koleksi novel dan komik untuk anak-anak, remaja maupun dewasa. Beragam kegiatan yang dilakukan oleh komunitas literasi khususnya dalam artikel ini mengamati dari pada komunitas literasi perpustakaan jalanan DIY. Sebagai bagian gerakan literasi masyarakat, komunitas tersebut berdiri sendiri tanpa domain dari pemerintah baik keterlibatan perpustakaan maupun pemerintah daerah. Kemandirian ini semakin menarik untuk melihat bagaimana proses dalam membangun komunitas literasi, manajerial oraganisasi, koleksi yang dimiliki dan value terhadap masyarakat. Metode yang dilakukan pada penelitian ini ialah kualitatif deskriptif, karena penulis akan menggambarkan secara umum dan mengamati langsung terhadap aktivitas dari komunitas literasi perpustakaan jalanan DIY dengan menggunakan analisis taksonomi yang bertujuan untuk memaparkan atau menjelaskan gejala-gejala yang menjadi objek penelitian. Sehingga dalam

${ }^{8}$ Billy Antora, Gerakan Literasi Sekolah: dari pucuk hingga akar sebuah refleksi. (Jakarta: Kemendikbud, 2017), 142. 
tulisan ini, penulis mengamati secara langsung dan ikut serta pada kegiatan komunitas literasi tersebut, dan penulis memfokuskan bagaimana aktivitas dari komunitas tersebut berjalan dan mempengaruhi masyarakat dalam meningkatkan literasi mereka.

\section{HASIL DAN PEMBAHASAN}

\section{A. Komunitas Literasi Perpustakaan Jalanan DIY}

Kegiatan membaca merupakan suatu tradisi dan aktivitas bagi orang yang menginginkan pengetahuan yang lebih mendalam, memiliki rasa optimis untuk suatu kesuksesan baik dalam pendidikan, bisnis, pemerintahan dan aktivitas sosial kemasyarakatan. Secara umum suatu komunitas dapat diartikan sebagai sekelompok orang yang saling berinteraksi didalam masyarakat, paguyuban ataupun daerah tertentu. Sementara literasi dapat diartikan sebagai suatu kemampuan individu dalam mengolah informasi, membaca, menulis, menggunakan media dan aktivitas pengetahuan lainnya untuk kemudian dapat dijaikan kemampuan dalam hidup bermasyarakat. Menurut Kemendikbud "literasi dipahami sebagai kemampuan mengakses, mencerna, dan memanfaatkan informas secara cerdas. Penumbuhan budaya baca menjadi sarana untuk mewujudkan warga sekolah, masyarakat, dan keluarga yang literat, dekat dengan buku, dan terbiasa menggunakan bahan bacaan dalam memecahkan beragam persoalan kehidupan". 9

Untuk mencapai hal ini maka perlu kiranya segenap masyarakat ikut serta dalam menyebarkan virus literasi secara nasional. Sementara komunitas literasi digambarkan

${ }^{9}$ Indonesia. Kemendikbut, Panduan Gerakan Literasi Nasional (Jakarta: Kemendikbut, 2017), 25. 
sebagai suatu kumpulan individu untuk dapat memberikan keteladanan, mendukung pelaksanaan program secara mandiri dan gotong royong, memberikan dukungan pada satuan pendidikan, menggerakkan anggota masyarakat, mendorong terbentuknya kolaborasi pengembangan literasi dan melaksanakan pengawasan serta evaluasi terhadap program komunitas literasi. 10

Sementara menurut Muhsin Kalida ${ }^{11}$ taman bacaan masyarakat atau komunitas literasi ialah suatu lembaga yang melayani kebutuhan masyarakat akan informasi terhadap ilmu pengetahuan dalam bentuk bahan bacaan dan bahan pustaka lainnya. Keberadaan komunitas literasi dan taman baca masyarakat menjadi suatu perluasan terhadap menumbuhkan minat baca, menulis, kreasi dan aktivitas litarasi lainnya oleh masyarakat untuk masyarakat.

Menurut Ahmed dalam Marihesya ${ }^{12}$ dampak dari adanya perpustakaan komunitas ialah

1. Komunitas sebagai pembantu bagi perpustakaan untuk mencermati terhadap isu nasional

2. Perpustakaan menciptakan komunitas untuk kepentingan peluang untuk mencapai tujuan literasi kepada masyarakat

3. Perpustakaan membantu masyarakat dalam kemampuan literasi

4. Perpustakaan mendukung siswa dalam meningkatkatkan nilai ujiannya

\section{${ }^{10}$ Ibid}

${ }^{11}$ Muhsin Kalida Fundraising Taman Bacaan Masyarakat (TBM) (Yogyakarta: Aswaja dan Cakruk Publising, 2012), 2.

${ }^{12}$ Andri yanto, Saleha Rodiah dan Elnovani Lusiana, Model Aktiitas Gerakan Literasi BerbasisKomunitas di Sududt Baca Soreang (Jurnal Kajian Informasi \& Perpustakaan: Unpad. vol.2, no.1, 2016), 110. 
5. Perpustakaan membantu menghasilkan keterampilan dalam organisasi dan bisnis lokal

6. Perpustakaan mendukung untuk meningkatkan kemampuan diri

7. Perpustakaan berkontribusi untuk memperluas komunitas pengetahuan.

Sedangkan komunitas menurut Konentjaraningrat ${ }^{13}$ ialah suatu masyarakat dalam satu ketentuan/peraturan dan adanya suatu aturan terhadap interaksi pada anggota tersebut yang berupa adat-istiadat dan norma-norma yang berlaku, serta dengan adanya rasa indentitas yang mempersatukan semua anggota.

Sementara pada komunitas literasi Perpustakaan Jalanan DIY merupakan suatu kesatuan antara anggotanya dengan memiliki suatu semangat untuk menyebar literasi, dengan identitas terhadap visi yang sama yaitu menyebarkan pengetahuan melalui kegiatan literasi jalanan, para anggota komunitas mulai membangun pada Mei 2017, perpustakaan jalan DIY membuka lesahan di Pelataran Tugu DIY. Layanan dan diskusi setiap malam Sabtu dari jam 20:00-selesai. Komunitas ini berdiri dengan tujuan agar virus literasi dapat secara meluas tersebar ke masyarakat, selain di lesehan tugu layanan juga dilakukan di pelosokpelosok daerah. Perpustakaan jalanan DIY sendiri pada mulanya hanyalah segelintir orang dengan memiliki visi yang sama, kemudian membangun komunitas dengan modal sumbangan buku dari setiap perintis, sementara perpustakaan jalanan DIY belum memiliki struktur dan pedoman yang baku, komunitas ini lebih memprioritaskan

${ }^{13}$ Koentjaraningrat, Pengantar Ilmu Antropologi (Jakarta: Rineka Cipta, 2009), 125. 
pada kegiatan literasi dan kurang manajerial dalam pengelolaan. Ini sangat mengkhawatirkan akan terjadinya konflik dikemudian hari, untuk minimize setidaknya komunitas literasi ini membuat peraturan tertulis dan pedoman agar bisa optimal dalam mewujudkan cita utama komunitas tersebut, adapun beberapa hal yang perlu dilakukan komunitas ialah:

1. Membuat struktur komunitas

2. Membuat tugas pokok dan fungsi antar anggota komunitas

3. Merumuskan visi, misi dan tujuan secara tertulis

4. Membangun mitra kerjasama dengan perpustakaan umum, daerah dan lembaga perpustakaan seperti TMB lainnya

5. Perkaderan keanggotaan komunitas

Lima hal ini setidaknya bisa minimize terhadap konflik internal terjadi dikemudian hari, karena yang megelola komunitas ialah mahasiswa maka sudah sepantasnya untuk membangun manajerial secara tertulis.

\section{B. Aktivitas Perpustakaan Jalanan DIY}

Perpustakaan dan masyarakat bagaikan suatu mata uang yang tidak bisa dipisahkan, tetapi masih banyak masyarakat yang memisahkan diri dari perpustakaan. Sementara perpustakaan sendiri merupakan produk atau media yang dibangun oleh manusia itu sendiri. Dalam konteks ini, komunitas literasi seperti TBM atau komunitas Perpustakaan jalanan DIY merupakan suatu metode yang dilakukan masyarakat untuk masyarakat dalam meningkatkan semangat literasinya. Hal ini senada dengan pendapat Muhsin Kalida dimana TBM dapat turut serta 
dalam menciptakan iklim kondusif untuk mendorong dan menstimulasi masyarakat ${ }^{14}$.

Komunitas literasi memposisikan diri sebagai fasilitotor agar masyarakat lebih mudah untuk meningkatkan literasinya. Beberapa kegiatan komunitas yang dilakukan oleh perpustakaan jalanan DIY seperti:

1. Kegiatan membaca

2. Bedah buku

3. Diskusi

4. Kesenian

5. Bersosialisasi

6. Media sosial

Anggota dari komunitas tersebut juga belatar belakang dari ruang ilmiah (kampus) yang multi disiplin keilmuan. Salah satunya ialah Ula dimana ia merupakan penerus dari aktivitas rutinitas yang dilakukan dari tahun 2017, kegiatan-kegiatan yang diadakan oleh komunitas sampai saat ini belum begitu maksimal. Seperti yang dikatakan oleh Agus Munawar ${ }^{15}$ beragam kegiatan kreatif, rekreatif yang diselenggarakan oleh taman baca masyarakat ataupun komunitas literasi tidak terlepas dari kesediaan sekelompok masyarakat (relawan) untuk merelakan diri dan materi dalam menyebar luaskan kegiatn literasi. Agar kegiatan bisa berjalan dengan baik setidaknya komunitas melakukan,

1. Pengorganisasian komunitas, adanya koordinator agar komunitas dapat berjalan dengan standarnya untuk mengerahkan ke aktivitas yang sesuai dengan tujuan utama.

${ }^{14}$ Muhsin Kalida, TBM PKBM: Model dan Strategi Pengembangannya

(Yogyakarta: Cakruk Pulishing.Kalida, 2014), 3.

${ }^{15}$ Anggadhitya, R., \& Dinar, A. Relawan Bidik Celah: Cerita Seru Sudut Baca Soreang (Soreang: SBS Publishing, 2014) 
2. Penggerakan actualiting, dalam artian komunitas mampu menggerakkan anggotanya agar bisa fokus untuk melaksanakan tugas dan tanggungjawab masing-masing.

3. Controlling komunitas, dalam artian komunitas memiliki pengawasan untuk mengamati setiap kegiatan yang dilakukan dan bisa melihat objek pelayanan agar maksimal terlaksana dan koleksi dimanfaatkan oleh pengunjung.

Beberapa hal diatas perlu kiranya dikaji kembali oleh komunitas literasi perpustakaan jalanan DIY agar target terhadap penyebaran virus literasi dapat dirasakan oleh masyarakat akan pengetahuan dan budaya literat yang disebarkan.

\section{Koleksi Perpustakaan Jalanan DIY dan Dampak Terhadap Masyarakat}

Koleksi merupakan kumpulan bahan pustaka dengan ragam format yang dimiliki. Dalam UU 43 tahun $2007^{16}$ tentang perpustakaan, dikatakan bahwa pengelolaan koleksi merupakan fungsi utama dari perpustakaan.

Komunitas perpustakaan jalanan DIY memiliki modal koleksi dari masing-masing aggota dengan membawa 5 (lima) buku per orang, dengan kata lain para anggota perpustakaan jalanan membawa buku pribadinya untuk di jadikan koleksi di ruang publik (pelataran tugu DIY), kegiatan ini berlangsung terus mernerus. Melihat respons yang positif dari kalangan masyarakat khususnya pada wisatawan dan beberapa komunitas lainnya, para pengiat lainnya turut membantu dalam menyediakan koleksi dan

\footnotetext{
${ }^{16}$ Indonesia, Pelaksanaan Undang-undang 43 Tahun 2007 Teantang perpustakaan.
} 
banyak para simpatisan yang bergabung degan perpustakaan jalanan DIY.

Koleksi sendiri saat ini banyak didapatkan dari swadaya masyarakat dan hibah dari berbagai instansi lainnya, koleksi yang dimiliki berupa:

1. Buku bacaan umum

2. Novel

3. Majalah

Untuk total keseluruhan dari hasil wawancara dan pengamatan langsung penulis dengan komuntas tersebut, maka secara umum buku fiksi berjumlah 130, buku non fiksi 170, majalah 57, data ini penulis dapatkan dari menghitung langsung di lesehan komunitas, dan sebagian koleksi masih berada di rumah Ula (si pegiat komunitas) diperkirakan 300an.

Dengan koleksi sebanyak itu, perpustakaan jalanan DIY sendiri belum memiliki dampak yang meluas terhadap masyarakat. Maka dalam hal ini, perlu adanya penguatan terhadap pendamping yang menyajikan bahan bacaan tersebut. Pendampingan dalam mengembangkan aktivitas bagi pengguna sangat diperlukan untuk dapat menguji kemampuan, memacu kreativitas, mengeksplorasi inovasi dan meningkatkan daya saing ${ }^{17}$. Dalam artian sumber daya para pegiat literasi memang untuk dapat ditingkatkan dari setiap waktunya, hal ini perlu dilakukan untuk mengingat bahwa kegiataa literasi merupakan visi jangka panjang yang harus melibatkan ruang publik. Oleh karena itu, untuk meningkatkan branded komunitas maka komunitas dengan

${ }^{17}$ Op.cit., Billy Antora. 142. 
koleksi tersebut harus bisa melahirkan penulis ataupun literat dalam bidang lainnya.

Proses ini perlu dilakukan untuk merubah kelemahan masyarakat Indonesia dalam budaya literasinya, selain itu dengan adanya ragam koleksi dan didampingi oleh pendamping yang tepat, maka untuk membuka suatu kajian atau diskusi ilmiah terhadap berbagai isu nasional dan internasional dapat terlaksana semaksimal mungkin, sehingga dampak perpustakaan jalanan DIY dirasakan oleh masyarakat dan akan melahirkan kemampuan literat untuk masyarakat lebih meningkat, komunitas literasi tidak hanya sebagai trend untuk gaya-gayaan tetapi bisa menghasilkan orang-orang yang kompetens. Pada dasarnya suatu komunitas literasi bukan hanya dapat mengembangkan jumlah koleksi yang dimiliki akan tetapi mempunyai tanggungjawab atas berjalannya suatu transfer informasi pengetahuan untuk mencerdaskan masyarakat.

\section{KESIMPULAN}

Komunitas literasi Perpustakaan jalanan DIY, menunjukkan kepada para pegiat literasi untuk lebih aktif dalam menyebarkan virus literat kemasyarakat. Komunitas literasi sangat membantu masyarakat untuk meningkatkan kemampuan dalam ilmu pengetahuan, sehingga dengan adanya komunitas ini maka masayarakat yang berakhir pekan mengunjungi pelataran tugu DIY dapat memanfaatkan koleksi-koleksi komunitas literasi. Beberapa kekurangan seperti manajerial terhadap keanggotaan, koleksi dan pendampingan perlu untuk ditingktkan dan menjadi perhatian oleh anggota komunitas dan lembaga informasi lainnya, untuk mendukung agar komunitas literasi Perpustakaan jalanan DIY dapat berjalan maksimal dan melahirkan para pegiat literasi 
baru serta para penulis-penulis baru juga para intelektual dalam berbagai bidang pengetahuan, selain menyajikan buku-buku perpustakaan jalanan DIY juga menyajikan kesenian sebagai hiburan diakhir pekan.

\section{LAMPIRAN}

Diskusi tentang perkembangan komunitas dan target kemunitas kedepan

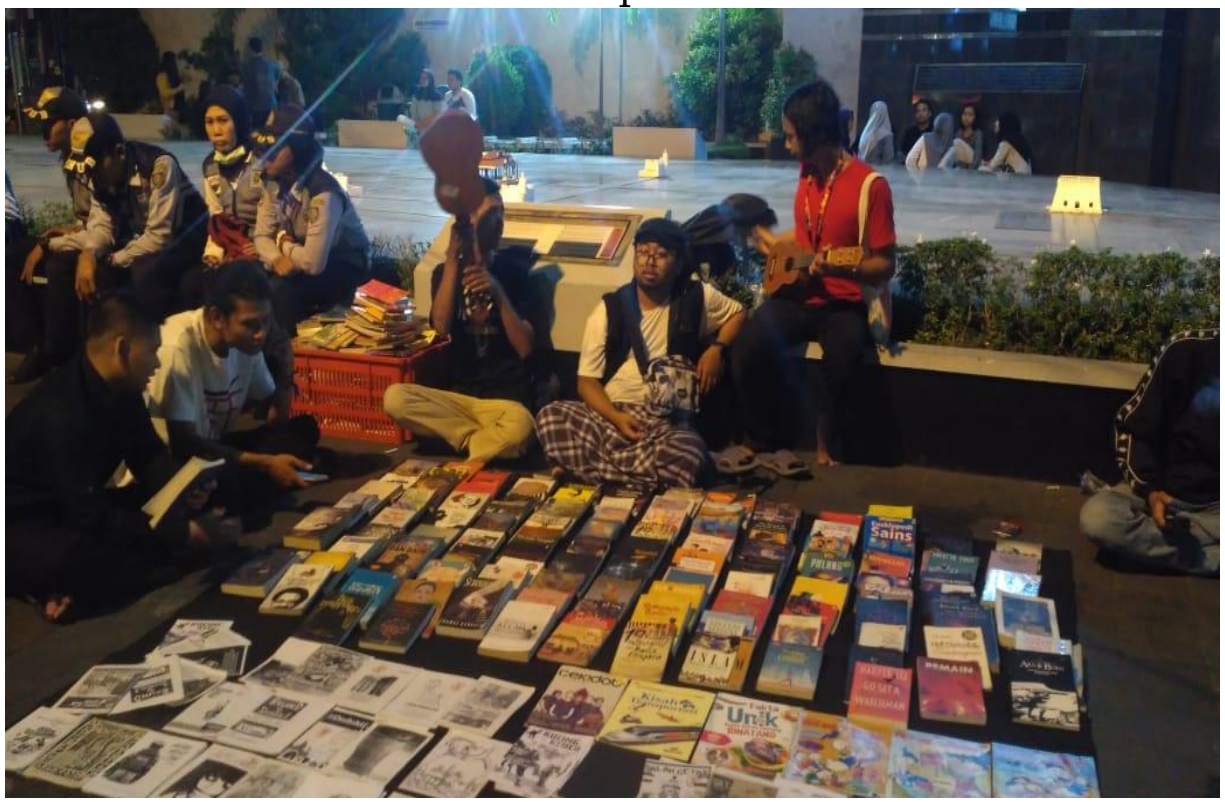

Pengunjung dari Jawa Timur (komitas literasi), berbagi informasi dan pengalaman

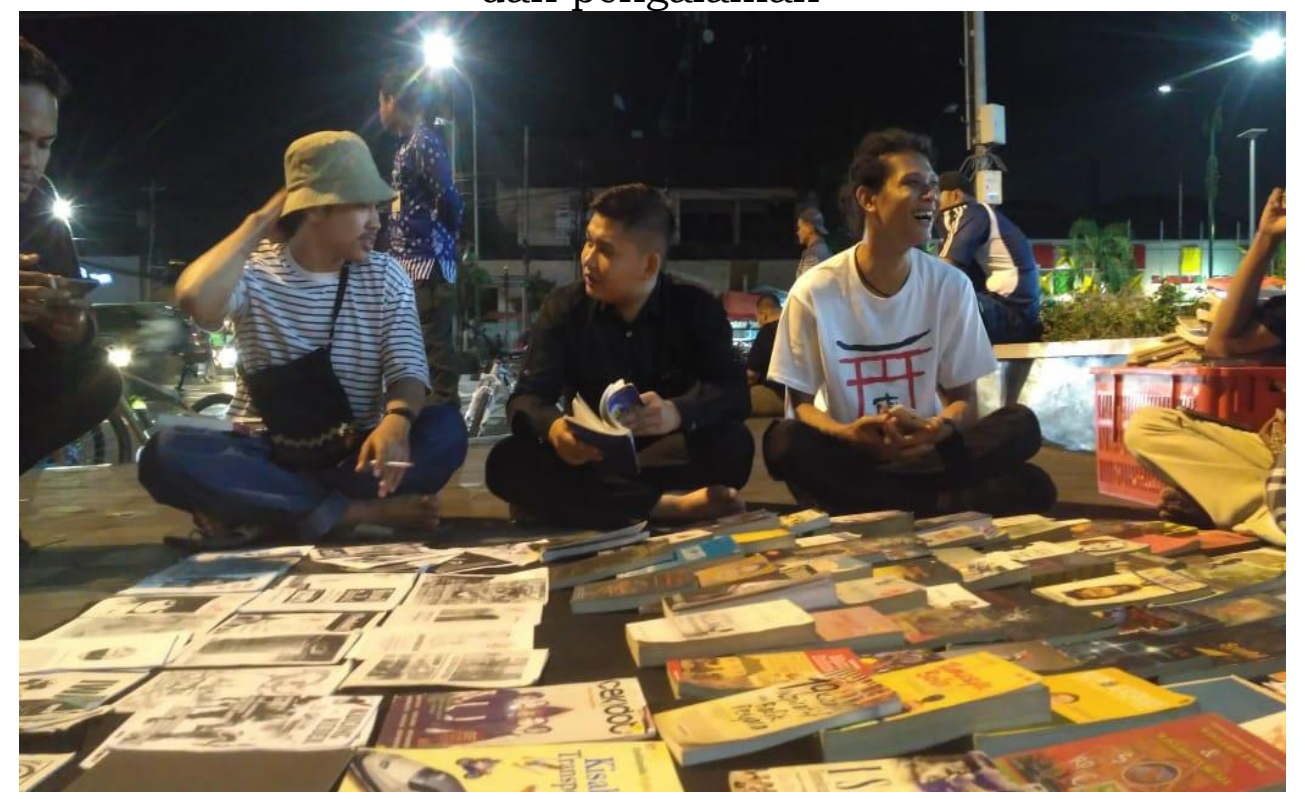




\section{DAFTAR PUSTAKA}

Andri yanto, Saleha Rodiah dan Elnovani Lusiana, Model Aktiitas Gerakan Literasi BerbasisKomunitas di Sududt Baca Soreang. Jurnal Kajian Informasi \& Perpustakaan: Unpad. vol.2, no.1, 2016.

Anggadhitya, R., \& Dinar, A. Relawan Bidik Celah: Cerita Seru Sudut Baca Soreang. Soreang: SBS Publishing, 2014.

Billy Antora, Gerakan Literasi Sekolah: dari pucuk hingga akar sebuah refleksi. Jakarta: Kemendikbud, 2017.

Hartono, dasar-dasar Manajemen Perpustakaan dari Masa ke Masa. Malang: UIN Maliki Press, 2015.

Indonesia. Kemendikbut, Panduan Gerakan Literasi Nasional. Jakarta: Kemendikbut, 2017.

Indonesia, Pelaksanaan Undang-undang 43 Tahun 2007 Teantang perpustakaan.

Koentjaraningrat, Pengantar Ilmu Antropologi. Jakarta: Rineka Cipta, 2009.

Muhsin Kalida, Fundraising Taman Bacaan Masyarakat (TBM). Yogyakarta: Aswaja dan Cakruk Publising, 2012.

----------, TBM PKBM: Model dan Strategi Pengembangannya. Yogyakarta: Cakruk Pulishing.Kalida, 2014. 